\title{
Teknologi Marinasi Daging Ayam Broiler Dengan Ekstrak Buah Nenas (Ananas comosus (L). Merr) Terhadap Kualitas Mikrobiologi
}

\section{Broiler Chicken Marinade Technology With Fruit Extract Nenas (Ananas comosus (L). Merr) On Microbiological Quality}

\section{Ludfia Windyasmara*, Ahimsa Kandi Sariri}

Program Studi Peternakan, Fakultas Pertanian, Universitas Veteran Bangun Nusantara

Jl. Letjen Sujono Humardani No. 1, Jombor, Sukoharjo Jawa Tengah, Indonesia

\author{
Article history \\ Received: Feb 24, 2021; \\ Accepted: Aug 18, 2021 \\ * Corresponding author: \\ E-mail: \\ windyasmaraludfia@gmail.com

\section{DOI:} \\ 10.46549/jipvet.v11i3.190
}

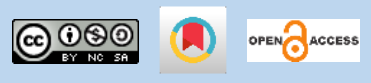

\begin{abstract}
This study aims to determine the effect of the microbiological quality of broiler chicken meat that is marinated using pineapple extracts with different storage times at refrigerator temperature (180C). The stages of this research consisted of 2 stages, namely the first stage of making pineapple extract from fresh pineapples and the second stage was the marination process in which the broiler chicken meat samples were marinated using pineapple extract with a concentration of $30 \%$. The experimental design used in this study was a completely randomized design (CRD) with one treatment factor ( 0 days, 3 days, 6 days, 9 days and 12 days) with each treatment repeated 4 times, in order to obtain $5 \times$ experimental units. $4=20$ experimental units. The microbiological analysis observed was the inhibition zone analysis and Total Plate Count (TPC). Giving marination with pineapple extract to the storage time of chicken meat has a significant effect on the inhibition zone. The highest zone of inhibition was $3.23 \mathrm{~mm}$ (for 6 days) while the lowest zone of inhibition was $2.21 \mathrm{~mm}$ (for 0 days). Provision of pineapple extract marination on the storage time of broiler chicken has a significant effect on the TPC. The highest TPC was 2.29 (for 12 days) while the lowest TPC was 0.30 (for 0 days).
\end{abstract}

Keywords: Broiler chicken; Marination; Microbiological quality; Pineapple extract.

\section{Abstrak}

Penelitian ini bertujuan untuk mengetahui pengaruh kualitas mikrobiologi daging ayam broiler yang dimarinasi menggunakan ekstrak buah nenas dengan lama penyimpanan yang berbeda pada suhu refrigerator $\left(18^{\circ} \mathrm{C}\right)$. Tahapan penelitian ini terdiri dari 2 tahapan yaitu tahap pertama pembuatan ekstrak buah nenas yang berasal dari buah nenas segar dan tahap kedua adalah proses marinasi dimana sampel daging ayam broiler dimarinasi dengan menggunakan ekstrak buah nenas dengan konsentrasi 30\%. Rancangan percobaan yang digunakan dalam penelitian ini adalah Rancangan Acak Lengkap (RAL) dengan satu faktor perlakuan (0 hari, 3 hari, 6 hari, 9 hari dan 12 hari) dengan masingmasing perlakuan diulang sebanyak $4 \mathrm{kali}$, sehingga diperoleh unit percobaan 5 x $4=20$ unit percobaan. Analisis mikrobiologi yang diamati adalah analisis zona hambat dan Total Plate Count (TPC). Pemberian marinasi dengan ektrak buah nenas terhadap lama penyimpanan daging ayam berpengaruh nyata terhadap zona hambat. Zona hambat tertinggi $3,23 \mathrm{~mm}$ (selama 6 hari) sedangkan zona hambat terendah $2,21 \mathrm{~mm}$ (selama 0 hari). Pemberian marinasi ekstrak buah nenas terhadap lama penyimpanan daging ayam broiler berpengaruh nyata terhadap TPC. TPC tertinggi 2,29 (selama 12 hari) sedangkan TPC terendah 0,30 (selama 0 hari).

Kata Kunci: Daging broiler; Ekstrak nanas; Kualitas mikrobiologi; Marinasi. 


\section{PENDAHULUAN}

Daging unggas merupakan sumber protein hewani yang baik, karena mengandung asam amino esensial yang lengkap dan dalam jumlah perbandingan yang seimbang. Daging ayam yang kaya akan kandungan zat-zat nutrisi seperti protein, lemak, karbohidrat, mineral dan vitamin serta $\mathrm{pH}$ yang netral merupakan media yang sangat baik untuk pertumbuhan mikroorganisme. Pertumbuhan dan perkembangan mikroorganisme pada daging ayam dapat terjadi pada fase postmortem yaitu fase setelah hewan mati karena pada fase ini terjadi perubahan $\mathrm{pH}$ yang sangat berpengaruh terhadap tumbuhnya mikroorganisme, baik bakteri patogen maupun non patogen. Apabila daging ayam terkontaminasi terutama oleh bakteri patogen, maka akan sangat berbahaya bila dikonsumsi. Oleh karena itu kualitas daging ayam harus dijamin keamanannya selama fase postmortem.

Beberapa faktor yang mempengaruhi kualitas daging ayam adalah antemortem, proses pemotongan dan lama penanganan selama postmortem. Lama penanganan selama postmortem selain berpengaruh terhadap kualitas fisik dan kimia, juga berpengaruh terhadap kualitas mikrobiologi daging ayam (Sukamto et.,al, 2001). Kualitas karkas ayam dipengaruhi oleh pengeluaran darah, pencabutan bulu, pengeluaran jeroan, waktu pemotongan dan cara pemotongan (Veerkamp, 2000). Pengeluaran jeroan yang kurang hatihati dapat mengakibatkan kontaminasi mikroba terhadap karkas. Kontaminan ini umumnya berupa mikroflora yang ditemukan pada ileum dan caecum. Berdasarkan hasil penelitian Lu et al. (2003), ditemukan bakteri koliform dalam ileum dan caecum ayam broiler.

Salah satu metode pengolahan daging untuk menghambat pertumbuhan bakteri adalah metode marinasi. Marinasi merupakan proses perendaman daging sapi ke dalam bahan marinade, sebelum diolah lebih lanjut. Marinade adalah cairan berbumbu yang berfungsi meningkatkan keempukan, daya ikat air, masa simpan daging dan menurunkan susut masak (Alvarado dan Sams, 2003). Aplikasi marinade dapat dilakukan dengan cara direndam, diinjeksi atau diguling- gulingkan (tumbling) (Alvarado dan McKee, 2007). Salah satu bumbu yang dapat digunakan sebagai bahan marinasi daging sekaligus sebagai anti bakteri adalah ekstrak buah nenas.Nenas merupakan tanaman buah berupa semak dengan daging buah berwarna kuning yang mempunyai kandungan air yang dimiliki buah nanas adalah 90\%. Nenas kaya akan kalium, Kalsium, lodium, Sulfur, Khlor, Asam, Biotin, Vitamin B12, Vitamin E serta Enzim Bromelin. Anam et al., (2003) menyatakan keempukan daging ayam petelur afkir dapat ditingkatkan dengan penambahan enzim bromelin yang terdapat dalam buah nenas, karena enzim bromelin mampu memecah ikatan protein komplek dan merupakan katalis reaksi hidrolisis protein dalam daging, sedangkan penelitian zulfahmi, Pramono dan Hintono (2014), menyatakan bahwa kandungan asam pada kulit nenas dapat meningkatkan kadar protein terlarut pada daging itik tegal betina afkir. Pemberian air nenas efektif untuk meningkatkan sifat organoleptik (rasa, warna, aroma, dan keempukan) serta kualitas protein daging. Pemberian air buah nenas sebanyak $15 \%$ efektif untuk meningkatkan tingkat keempukan daging (Widjiati, 2005). Buah nenas juga mengandung mineral seperti kalium dan fosfor (Rismunandar, 1990). Kalium sangat berperan dalam meningkatkan rasa daging. Buah nanas memiliki kandungan zat aktif yaitu bromelin. Afrianti (2013) menyatakan bromelin mempunyai aktivitas antiinflamasi, aktivitas fibrinolitik, dan dapat mencegah agregasi platelet. Penelitian tentang efek antibakteri buah nanas pernah dilakukan pada Staphylococcus aureus, E. coli, Shigella sonnei, Salmonella, dan Streptococcus mutans.Selain itu bromelin yang diekstraksi dari buah nanas juga menunjukkan efek antibakteri terhadap bakteri E. coli, Proteus sp. Ekstrak aseton kulit nanas dapat menghambat pertumbuhanKlebsiella pneumoniae.Namun belum ada yang meneliti tentang efek antibakteri air perasan buah nanas terhadap bakteri Klebsiella pneumoniae. Klebsiella pneumoniae merupakan bakteri gram negatif yang dapat menyebabkaninfeksi nosokomial (hospitalacquired infections) dan infeksi komunitas (community-acquired infections). 


\section{MATERI DAN METODE}

\section{ALAT DAN BAHAN PENELITIAN}

Peralatan yang digunakan pada penelitian ini antara lain peralatan laboratorium seperti Timbangan Analitik (Ohaus), inkubator, autoclave, cawan petri, dryglassky, erlenmeyer, tabung reaksi, gelas ukur, bluetip, kertas saring.

Bahan baku penelitian yang digunakan pada pembuatan sampel penelitian ini adalah daging ayam broiler dan buah nenas yang didapatkan dari Pasar Ir. Soekarno yang berada di daerah Sukoharjo.

Bahan kimia untuk analisis kimia diantaranya adalah Potato dextrose agar (PDA), Natrium Agar (NA), bakteri E. Coli dan aquades.

\section{TAHAPAN PENELITIAN}

Tahapan penelitian ini terdiri dari 2 tahapan yaitu tahap pertama pembuatan ekstrak buah nenas yang berasal dari buah nenas segar dan tahap kedua adalah proses marinasi dimana sampel daging ayam broiler dimarinasi dengan menggunakan ekstrak buah nenas yang telah dibuat sebelumnya.

PEMBUATAN EKSTRAK NANAS. Buah nanas segar diparut, kemudian diperas menggunakan kain tipis untuk mendapatkan sarinya. Pada konsentrasi $30 \%$ yang digunakan dalam penelitian ini $30 \mathrm{ml}$ larutan sari buah nanas ditambahkan aquades hingga menjadi $100 \mathrm{ml}$.

PROSES MARINASI. Daging ayam broiler bagian dada dipotong hingga mempunyai lebar $10 \mathrm{~cm}$ pada masing-masing sisinya. Daging ayam broiler yang telah dipotong sesuai dengan ukuran direndam dalam larutan ekstrak nanas konsentrasi $30 \%$ dan disimpan di refrigerator pada suhu $18^{\circ} \mathrm{C}$ dan disimpan pada 0 hari, 2 hari, 4 hari, 6 hari dan 8 hari.

UjI ZONA HAMBAT (Muin et al., 2017). Aktivitas antimikroba dilakukan dengan metode cakram dengan beberapa modifikasi. Sampel yang diuji dipotong dengan alat perforator (pembolong kertas). Bakteri E. coli sebanyak $2 \mathrm{ml}$ dimasukkan ke cawan petri yang telah disterilkan dengan autoclave, kemudian dimasukkan Nutient Agar sebanyak $5 \mathrm{ml}$. Sampel edible film ditanam dalam media setelah agar mengeras. Sampel disimpan di dalam inkubator pada suhu $37{ }^{\circ} \mathrm{C}$ selama 24 jam. Kemudian mengukur zona bening yang merupakan lebar area bening yang terbentuk disekitar edible film diukur diameternya menggunakan jangka sorong.

total Plate Count (TPC) (Sipahelut et al., 2021). Metode Total Plate Count (TPC) dibedakan atas dua cara, yaitu metode tuang (pour plate), dan metode permukaan (surface /spread plate). Pada metode tuang, sejumlah sampel (1 $\mathrm{ml}$ atau o,1 $\mathrm{ml})$ dari pengenceran yang dikehendaki dimasukkan ke cawan petri, kemudian ditambahkan agar-agar cair steril yang didinginkan $\left(47-50{ }^{\circ} \mathrm{C}\right)$ sebanyak $15-20$ $\mathrm{ml}$ dan digoyangkan supaya sampelnya menyebar. Pada pemupukan dengan metode permukaan, terlebih dahulu dibuat agar cawan kemudian sebanyak $0,1 \mathrm{ml}$ sampel yang telah diencerkan dipipet pada permukaan media agar-agar tersebut. Kemudian diratakan dengan batang gelas melengkung yang steril selanjutnya di inkubasi $37{ }^{\circ} \mathrm{C}$ selama $2 \times 24$ jam. Jumlah koloni dalam sampel dapat dihitung sebagai berikut

$$
\text { Koloni } \mathrm{ml}=\text { jumlah koloni percawan } x \frac{1}{\text { faktor pengencer }}
$$

\section{RANCANGAN PERCOBAAN}

Rancangan percobaan yang digunakan dalam penelitian ini adalah Rancangan Acak Lengkap (RAL) dengan satu faktor perlakuan, yaitu lama penyimpanan $(\mathrm{P})$, dengan masingmasing perlakuan diulang sebanyak 4 kali, sehingga diperoleh unit percobaan $5 \times 4=20$ unit percobaan.

P0 : Daging ayam broiler yang dimarinasi disimpan selama 0 hari (kontrol)
P1 : Daging ayam broiler yang dimarinasi disimpan selama 2 hari

P2 : Daging ayam broiler yang dimarinasi disimpan selama 4 hari

P3 : Daging ayam broiler yang dimarinasi disimpan selama 6 hari

P4 : Daging ayam broiler yang dimarinasi disimpan selama 8 hari

\section{ANALISIS LABORATORIUM}

Analisis yang dilakukan pada penelitian ini meliputi analisis mikrobiologi. Analisis 
mikrobiologi yang diamati adalah: Analisis Zona Hambat dan Total Plate Count (TPC).

ANALISIS DATA

Data yang diperoleh pada analisis fisik dan kimia dihitung secara statistik menggunakan software SPSS versi 17.0 dengan metode Anova kemudian dilanjutkan dengan uji Duncan's Multiple Range Test (DMRT) jika terdapat perbedaan yang nyata antar perlakuan.

\section{HASIL DAN PEMBAHASAN}

Hasil dari penelitian kualitas mikrobiologi daging ayam broiler terhadap lama penyimpanan yang di marinasi dengan ekstrak buah nenas (Ananas comosus (L). Merr) dengan parameter yang diamati adalah kualitas mikrobiologi yang meliputi uji zona hambat dan Total Plate Count (TPC) sebagai berikut :

\section{ZONA HAMBAT}

Uji zona hambat pada daging ayam broiler terhadap lama penyimpanan yang di marinasi dengan ekstrak buah nenas (Ananas comosus (L). Merr) merupakan salah satu parameter yang penting dalam standar mutu daging ayam. Data prosentase uji zona hambat daging ayam broiler pada lama penyimpanan yang berbeda dengan dimarinasi dengan ekstrak buah nenas (Ananas comosus (L). Merr) disajikan pada Tabel 1.

Tabel 1. Rerata uji zona hambat pada daging ayam broiler terhadap lama penyimpanan yang di marinasi dengan ekstrak buah nenas (Ananas comosus (L). Merr) (mm)

\begin{tabular}{ccccccr}
\hline \multirow{2}{*}{ Ulangan } & \multicolumn{5}{c}{ Perlakuan } \\
\cline { 2 - 6 } & P0 & P1 & P2 & P3 & P4 \\
\hline U1 & 2,17 & 2,27 & 3,13 & 3,12 & 2,80 \\
U2 & 2,23 & 2,18 & 3,18 & 3,37 & 2,83 \\
U3 & 2,26 & 2,33 & 3,27 & 3,23 & 2,66 \\
U4 & 2,21 & 2,25 & 3,33 & 3,17 & 2,77 \\
U5 & 2,22 & 2,34 & 3,27 & 3,12 & 2,66 \\
\hline Rerata & $2,21^{\mathrm{a}}$ & $2,27^{\mathrm{a}}$ & $3,23^{\mathrm{c}}$ & $3,20^{\mathrm{c}}$ & $2,74^{\mathrm{b}}$ \\
\hline
\end{tabular}

Ket $^{\mathrm{a}, \mathrm{b}, \mathrm{c}}$ : superskrip yang berbeda menunjukan perbedaan yang nyata $(\mathrm{P}<0,05)$

Hasil analisis menunjukkan bahwa lama penyimpanan daging ayam dengan teknologi marinasi menggunakan ekstrak buah nenas berpengaruh nyata terhadap nilai zona hambat E. coli (Tabel 1). Nilai zona hambat antara perlakuan $\mathrm{P} 0(2,21 \mathrm{~mm})$ dengan $\mathrm{P} 1(2,27 \mathrm{~mm})$, P2 $(3,23 \mathrm{~mm})$, P3 $(3,20 \mathrm{~mm})$ menunjukkan perbedaan tidak nyata, sedangkan perlakuan P4 menunjukkan perbedaan nyata. Nilai zona hambat dapat dilihat bahwa, daya hambat terendah sebesar $2,27 \mathrm{~mm}$ dan daya hambat tertinggi sebesar $3,23 \mathrm{~mm}$. Nilai zona hambat yang semakin besar menunjukkan daya hambat yang semakin besar terhadap bakteri, sedangkan nilai zona hambat yang semkin kecil menunjukkan daya hambat yang kecil terhadap bakteri.

Semakin lama penyimpanan pada daging ayam broiler yang di marinasi dengan ekstrak buah nenas (Ananas comosus (L). Merr) berpengaruh nyata terhadap nilai zona hambat daging ayam. Adanya marinasi dengan ekstrak buah nenas (Ananas comosus (L). Merr) membuat perpindahan oksigen dari lingkungan ke produk dapat dihambat sehingga pertumbuhan bakteri aerob juga terhambat. Marinasi dengan ekstrak buah nenas (Ananas comosus (L). Merr) mampu menutupi seluruh permukaan daging ayam akan menghambat masuknya $\mathrm{O}^{2}$ dan uap air melalui permukaan daging ayam, sehingga mikroba sulit untuk berkembang. (Murtini, 2003)

Daging ayam broiler yang dimarinasi dengan ekstrak buah nenas (Ananas comosus (L). Merr) mengalami peningkatan nilai zona hambat dari hari ke-0 sampai hari ke-2 hal ini dikarenakan mengindifikasikan bahwa adanya kandungan fenol yang terdapat pada ekstrak buah nenas. Menurut Mardiah (2009) peningkatan nilai zona hambat pada sampel dari hari ke-0 sampai hari ke-2 senyawa fenol dapat masuk ke dalam sitoplasma sel bakteri dan merusak sistem kerja sel dan berakibat lisisnya sel bakteri. Penurunan dari hari ke-2 sampai hari ke-8 nilai zona hambat mengindifikasikan bahwa adanya marinasi 
dengan ekstrak buah nenas (Ananas comosus (L). Merr) yang sudah tidak efektif menghambat aktivitas bakteri Escherichia coli selama penyimpanan sehingga menimbulkan mikroba tumbuh. Peningkatan waktu penyimpanan menyebabkan rusaknya protein oleh bakteri (Lu, et.,al, 2003). Adanya marinasi dengan ekstrak buah nenas (Ananas comosus (L). Merr) membuat perpindahan oksigen dari lingkungan ke produk dapat dihambat sehingga pertumbuhan bakteri aerob juga terhambat. Marinasi dengan ekstrak buah nenas (Ananas comosus (L). Merr) yang menutupi seluruh permukaan daging ayam akan menghambat masuknya $\mathrm{O}^{2}$ dan uap air melalui permukaan daging ayam, sehingga mikroba sulit untuk berkembang. (Sukamto, 2001).

\section{TOTAL Plate COUNT (TPC)}

Total Plate Count (TPC) merupakan analisis populasi total mikroba yang mencerminkan jumlah keseluruhan mikroba pada daging ayam broiler. PengujianTotal Plate Count dilakukan dengan pengenceran hingga pegenceran ke $6\left(10^{6}\right)$ karena pada pengenceran sampai keenam dapat terlihat dan dihitung total populasi mikrobanya. Data Total Plate Count daging ayam broiler pada lama penyimpanan yang berbeda dengan dimarinasi dengan ekstrak buah nenas (Ananas comosus (L). Merr) dapat dilihat pada Tabel 2.

Tabel 2. Rerata Total Plate Count (TPC) daging ayam broiler dengan marinasi dengan ekstrak buah nenas (Ananas comosus (L). Merr) (cfu/gr)

\begin{tabular}{cccccc}
\hline \multirow{2}{*}{ Ulangan } & \multicolumn{3}{c}{ Perlakuan } & & \\
\cline { 2 - 6 } & $\mathrm{P} 0$ & $\mathrm{P} 1$ & $\mathrm{P} 2$ & $\mathrm{P} 3$ & $\mathrm{P} 4$ \\
\hline U1 & $31 \times 10^{6}$ & $45 \times 10^{6}$ & $76 \times 10^{6}$ & $172 \times 10^{6}$ & $211 \times 10^{6}$ \\
U2 & $34 \times 10^{6}$ & $37 \times 10^{6}$ & $78 \times 10^{6}$ & $158 \times 10^{6}$ & $223 \times 10^{6}$ \\
U3 & $33 \times 10^{6}$ & $44 \times 10^{6}$ & $63 \times 10^{6}$ & $163 \times 10^{6}$ & $233 \times 10^{6}$ \\
U4 & $29 \times 10^{6}$ & $41 \times 10^{6}$ & $72 \times 10^{6}$ & $175 \times 10^{6}$ & $244 \times 10^{6}$ \\
U5 & $27 \times 10^{6}$ & $44 \times 10^{6}$ & $78 \times 10^{6}$ & $178 \times 10^{6}$ & $237 \times 10^{6}$ \\
\hline Rerata & $30 \times 10^{6}$ & $42 \times 10^{6}$ & $73 \times 10^{6}$ & $169 \times 10^{6}$ & $229 \times 10^{6}$ \\
\hline
\end{tabular}

Ket $^{\text {a,b,c,d }}$ : superskrip yang berbeda menunjukan perbedaan yang nyata $(\mathrm{P}<0,05)$

Hasil analisis menunjukkan bahwa lama penyimpanan daging ayam broiler dengan marinasi dengan ekstrak buah nenas (Ananas comosus (L). Merr) berpengaruh nyata terhadap Total Plate Count (TPC) daging ayam. Total Plate Count (TPC) daging ayam mengalami peningkatan bertahap pada penyimpanan $\mathrm{P} 0, \mathrm{P} 1, \mathrm{P} 2, \mathrm{P} 3$, dan $\mathrm{P} 4$. Total Plate Count (TPC) tertinggi diperoleh pada perlakuan P4 sebesar $229 \times 10^{4}$ dan terendah pada perlakuan P0 sebesar $30 \times 10^{4}$ Total Plate Count (TPC) dari keempat perlakuan ini baik untuk dikonsumsi, sesuai dengan syarat standar mutu SNI daging ayam (2009) yaitu maksimal Eschericia coli < 3/gram.

Total Plate Count (TPC) mengalami peningkatan bertahap dari hari ke- $0,2,4,6$ dan 8. Semakin lama penyimpanan pada suhu refrigerator akan semakin banyak basa yang dihasilkan akibat semakin meningkatnya aktivitas mikroorganisme yang pada akhirnya mengakibatkan terjadinya pembusukan.
Menurut Alvarado et.,al. (2003) proses pembusukan akan diikuti dengan peningkatan $\mathrm{pH}$, dan keadaan ini akan diikuti pula dengan peningkatan pertumbuhan bakteri. Pertumbuhan mikroba pada produk pangan dipengaruhi oleh adanya perpindahan oksigen selama penyimpanan. Hal ini dikarenakan adanya lapisan marinasi dengan ekstrak buah nenas (Ananas comosus (L). Merr)yang melapisi seluruh permukaan daging ayam. Lapisan senyawa antimicrobial mempunyai kemampuan untuk melindungi produk dari mikroba. Menurut Evanuarini (2011) batas toleransi untuk cemaran koloni mikroba produk daging tidak boleh lebih dari $1 \times 10^{5}$ koloni/gram, Salmonella sp negatif /25 gram, E. coli < 3/gram serta S.aureus $1 \times 10^{2}$ koloni/gram. Daging merupakan bahan pangan yang sangat beresiko. Perlakuan penyimpanan, pemrosesan, pengemasan dan distribusi yang tidak baik akan mengakibatkan resiko tumbuhnya mikroorganisme. Potensi 
kontaminasi mikrobiologi tergantung dari status fisiologis ternak pada saat dipotong, kontaminasi dari rumah pemotongan hewan selama pemrosesan, temperatur pada saat penyimpanan dan kondisi lain pada saat distribusi yang dapat mempengaruhi laju dari mikroba (Aberle et al. 2001).

\section{KESIMPULAN}

Pemberian marinasi dengan ektrak buah nenas terhadap lama penyimpanan daging ayam berpengaruh nyata terhadap zona hambat dan Total Plate Count (TPC). Pemberian marinasi dengan ekstrak buah nenas masih efektif untuk penyimpanan daging ayam broiler hingga hari ke-8.

\section{DAFTAR PUSTAKA}

Aberle E. D., Forrest J. C., Gerrard D. E. and Mills E. W. 2001. Principles of meat science. 4th ed. Kendall/Hunt Publishing Co., Dubuque, IA.

Afrianti M., Dwiloka B. and Setiani B. (2013). "Total bakteri, pH, dan kadar air daging ayam broiler setelah direndam dengan ekstrak daun senduduk (Melastoma Malabathricum L.) selama masa simpan". Jurnal Pangan dan Gizi 4(7): 115443, https://doi.org/10.26714/jpg.4.1.2013.

Alvarado, C. Z. and A. R. Sams. 2003. Injection marination strategies for remediation of pale, exudative broiler breast meat. Poult. Sci. 82(8):1332--1336.

Evanuarini H dan Huda. 2011. Quality of Dendeng Giling on Different Sugar addition. Jurnal Ilmu-Ilmu Peternakan. 21(2): $1-10$

Handarini. 2014. Potensi Ekstrak Bunga Rosella (Hibiscus sabdariffa L.) Sebagai pengawet alami yang diaplikasikan pada daging ayam segar pengganti formalin. Jurnal Agroknow. Vol. 2(1): 1-7

Lu, J., U. Idris, B. Harmon, C. Hofacre, J.J. Maurer dan M.D. Lee. 2003. Diversity and succession of the intestinal bacterial community of the maturing broiler chicken. Applied and Environmental Microbiology. 64(11): 6816-6824. Lukman

Mardiah, Amelia L dan Sulaiman A. 2009. Ekstraksi Kulit Batang Rosella (Hibiscus Sabdariffa L.) Sebagai pewarna merah alami. Jurnal Pertanian. Vol. 1(1): 1-8

Murtini, E.S, dan Qomarudin. 2003. Pengempukan daging dengan enzim protease tanaman biduri (Calotropis gigantea). J. Teknologi dan Industri Pangan. 14(3):266-268.

Rismunandar. 1990. Membudidayakan Tanaman Buah-buahan. Yogyakarta: Kanisius.

Sipahelut et al. 2021. Level Pemberian Tepung Rosella (Hibiscus sabdariffa Linn) Terhadap Kualitas Dendeng Babi.Jurnal Ilmu Peternakan dan Veteriner Tropis (Journal of Tropical Animal and Veterinary Science), Juli 2021, Vol. 11 No. 2 hal. $125-131$

Sukamto, H., K. Widayaka dan E. Tugiyanti. 2001. Keempukan daging ayam broiler di bawah pengaruh umur pemotongan dan umur daging. Jurnal Peternakan Tropik. 1: 1. Lembaga Penelitian dan Pengembangan Teknologi Tepat Guna (LP2T2P).

Suryanto E dan Wehantouw F. 2009. Aktivitas Penangkap Radikal Bebas dari Ekstrak Fenolik Daun Sukun (Artocarpus altilis F) Chem. Prog. Vol. 2(1): 1-7 